УДК 616.72-002.772-071-08

DOI 10.11603/2411-1597.2020.4.11870

\title{
РЕВМАТОЇДНИЙ АРТРИТ - ІСТОРІЯ, СУЧАСНІ ПОГЛЯДИ, ТАКТИКА, РЕЗУЛЬТАТ
}

\author{
А. А. Гонт, О. І. Зарудна \\ Тернопільський національний медичний університет \\ імені І. Я. Горбачевського мОз Украӥни
}

У статті висвітлено історичні аспекти та сучасні погляди на ревматоїдний артрит як мультифакторіальне захворювання. Наведено інформацію щодо новітніх методів діагностики та лікування з метою покращення прогнозу для пацієнта.

\section{RRHEUMATOID ARTHRITIS - HISTORY, MODERN VIEWS, TACTICS, RESULTS}

\author{
A. A. Hont, O. I. Zarudna
}

\section{Horbachevsky Ternopil National Medical University}

The article highlights the historical aspects and current views on rheumatoid arthritis as a multifactorial disease. New information about the latest methods of investigation and treatment to improve patients' prognosis is presented.

Вступ. Ревматоїдний артрит (РА) - хронічне прогресуюче системне аутоімунне захворювання сполучної тканини з невідомою етіологією, для якого характерним є симетричний ерозивний артрит та широкий спектр позасуглобових (системних) проявів [1].

Перший клінічний опис цієї патології у 1800 р. приписують Augustin-Jacob Lander-Beauvais. Сам автор назвав хворобу - «проста астенічна подагра» (goutte asthenique primitif). Benjamin Brodie описав повільне прогресування синовіїту шляхом втягнення в патологічний процес суглобової сумки та піхви сухожилля. А термін «ревматоїдний артрит» був запропонований A. B. Garrod у 1858 р., він також віддиференціював його від подагри у 1892 р. (James S. Louie, MD).

Eniдеміологія. РА - основна проблема сучасної ревматології у зв'язку зі значним поширенням цього захворювання серед дорослого населення (близько 0,5-2,0\%), що становить 50-100 нових випадків на 100000 населення. Співвідношення між жінками та чоловіками, які хворіють на РА, 2-3:1, при цьому уражаються представники всіх вікових груп, включаючи дітей та осіб похилого віку, однак пік дебюту захворювання припадає на 30-55 років [2]. В Україні розповсюдженість РА становить 340 випадків на

(c) А. А. Гонт, О. І. Зарудна, 2020
100000 дорослого населення, а жінки хворіють на ревматоїдний артрит у 3-4 рази частіше, ніж чоловіки. Однак у серопозитивних за ревматоїдним фактором (РФ) пацієнтів ці відмінності менш очевидні [6]. РА належить до захворювань, які вкорочують тривалість життя та призводять до серйозної інвалідизації хворих. Майже 50 \% пацієнтів протягом перших 10 років від початку хвороби стають інвалідами. Близько 33 \% хворих, які працювали до моменту виникнення захворювання, змушені звільнитися уже в перші 5 років хвороби. Крім цього, порівняно з людьми цього ж віку і статі, які не хворіють на ревматоїдний артрит, смертність хворих на РА вища у 2-2,5 раза. У цілому РА скорочує тривалість життя пацієнтів на 5-10 років, у тому числі й за рахунок коморбідності (James O'Dell, MD). Економічні втрати через PA $є$ співрозмірними з витратами на лікування при ішемічній хворобі серця та пухлинних захворюваннях [2]. Водночас активна терапія базовими хворобомодифікуючими препаратами в перші роки захворювання зменшує інвалідизацію на 30 \%.

Ревматоїдний артрит охоплює усі верстви населення, незалежно від освіти, професії чи творчих здібностей. Зокрема, серед відомих пацієнтів із РА співачка Едіт Піаф, кіноактриси Розалін Рассел та Катрін

30 ISSN 2411-1597. МЕДСЕСТРИНСТВО. 2020. № 4 
Хепберн, кардіохірург Крістіан Бернард, який виконав першу в світі трансплантацію серця, президенти США Томас Джефферсон, Джеймс Медісон і Теодор Рузвельт [James S. Louie, MD].

Хронічний перебіг хвороби, рання інвалідизація, великі економічні втрати, зумовлені вартістю лікування та «випаданням» пацієнтів зі соціально-економічного життя, їхня дезадаптація зумовлює актуальність та важливість вивчення, дослідження РА та вдосконалення стратегії лікування і реабілітації.

Основна частина. Оскільки етіологія РА невідома, великого значення надають пусковим чинникам екзогенного (куріння, вірус Епштейна - Барр, парвовірус В19, ретровіруси, суперантигени і стресорні білки бактерій) та ендогенного (цитруліновані білки і пептиди) походження. Додатково потенційно артритогенні чинники поділяють на: ад'ювантні (глюкани, ліпополісахариди, бактеріальну ДНК, куріння, компоненти мінеральних масел, вугільний пил) та аутоантигенні (колаген типів II, IX, X, XI, олігомерний матриксний білок хряща, протеоглікани).

Гіпотетично потенційні етіологічні чинники, взаємодіючи з генетичною схильністю, беруть не пряму, а опосередковану участь у розвитку РА $[3,4,6]$.

Існування генетичної схильності в розвитку РА підтверджує висока конкордатність у монозиготних близнюків, на відміну від дизиготних, та підвищений ризик захворіти на РА серед родичів першої лінії спорідненості.

Ризик розвитку РА асоційований з носійством антигену головного комплексу гістосумісності класу II HLA-DR4 і DR1, який включає більше 22 алелей. При вивченні індивідуальних алелей визначено два, найбільш тісно асоційованих з PA: DRB1*0401 i DRB1*0404. Носійство HLA-DRB1*0401 виявляють у 50-61 \% пацієнтів з PA, а HLA-DRB1 *0404 - в 27-37\% хворих на РА.

Патогенез. Основу патологічного процесу при РА становить системне аутоімунне запалення, яке більш за все уражає синовіальну оболонку суглобів. Саме розвиток прогресуючого неконтрольованого синовіального запалення відрізняє РА від інших хронічних запальних захворювань людини як ревматичної, так і неревматичної природи. Провідна морфологічна ознака ревматоїдного запалення - формування ектопічного вогнища гіперплазії синовіальної тканини. Інвазивний ріст цієї структури (пануса) призводить до руйнування суглобового хряща й субхондральної кістки. У синовіальній тканині визначають збільшення кількості синовіоцитів типу A, які схожі на макрофаги, i В, клітини, що нагадують фібробласти. Зростає товщина інтими. Наявна інфільтрація імунними та запальними клітинами (макрофагами, Т- і В-лімфоцитами, плазматичними і дендритними клітинами), утворюються фолікули, які складаються з лімфоїдних клітин і нагадують центри росту лімфатичних вузлів. Рання ознака ревматоїдного синовіїту - утворення нових судин (неоангіогенез). Цей процес асоційований 3 транссудацією та міграцією лімфоцитів у синовіальну тканину. Розвиток РА пов'язаний з генетично детермінованою Т-клітинною імунною відповіддю на широкий спектр потенційно патогенних (артритогенних) антигенів. 3 імунологічної точки зору в даному процесі переважає Th1-тип імунної відповіді, що супроводжується гіперпродукцією прозапальних цитокінів, таких як фактор некрозу пухлин-а (ФНП-а), інтерлейкіни (IL) IL-1, IL-2, IL-12, IL-7, IL-6, IL-17, IL-18 та інтерферон гамма, і призводить до переважання прозапальних інтерлейкінів над протизапальними. Важливе значення в цьому «коктейлі» запалення мають ФНП-а, IL-1, IL-6, які індукують синтез медіаторів, що підтримують запалення і спричиняють руйнування суглобів.

Механізми зв'язку між запаленням та ерозуванням при РA:

- аутоімунні В-лімфоцити не руйнуються в кістковому мозку і мігрують в суглоб до синовіальної оболонки, де взаємодіють з Т-лімфоцитами та іншими клітинами запалення, що викликають синовіїт;

- В-клітини рухаються і до субхондральної кістки, викликаючи остеїт;

- ерозії кістки спричиняються ФНП-а і ліганд-рецепторною системою (RANKL) через активацію остеобластів $[3,4,6]$.

\section{Стадії ревматоїдного артриту}

Рання стадія (безсимптомна) характеризується судинною та клітинною активацією.

Розгорнута стадія (швидка хронізація запалення) проявляється порушенням ангіогенезу, активацією ендотелію, клітинною міграцією; інфільтрацією активованими CD4+ Т-лімфоцитами синовіальної тканини, утворенням РФ та інших аутоантитіл, імунних комплексів; синтезом прозапальних цитокінів, простагландинів, металопротеаз, колагеназ.

Пізня стадія характеризується соматичними мутаціями та дефектами апоптозу синовіальних тканин.

Отже, РА - гетерогенне, мультифакторіальне захворювання. Чинники навколишнього середовища та генетично зумовлені фактори ризику призводять 
до формування різних варіантів перебігу хвороби. Це пояснює труднощі протизапальної терапії РА, що $€$ найефективнішою в межах досить вузького «терапевтичного вікна», після чого клітини-мішені втрачають здатність відповідати на фізіологічні «протизапальні» стимули та набувають резистентності до фармакологічного впливу [6].

\section{Клінічна характеристика ревматоїдного apmpumy}

Основним клінічним синдромом РА є артритичний, який супроводжується класичними ознаками запалення (rubor, tumor, calor, dolor et functio lesa). Артрит переважно симетричний, на ранній стадії захворювання - уражені суглоби зап'ястя, кистей і стоп. Найчастіше уражаються проксимальні міжфалангові, п'ясно-фалангові та плесно-фалангові суглоби. У подальшому в процес залучаються колінні, плечові, ліктьові та кульшові суглоби. Суглоби рук уражаються частіше, ніж суглоби ніг. Можливий нетиповий початок РА, наприклад - у формі моноартриту. Типовим $€$ залучення в процес шийного відділу хребта. На ранній стадії захворювання виявляють незначну гіпертермію без гіперемії шкіри, болючість суглобів під час стискання, набряк суглобів та навколосуглобових м'яких тканин, ексудат у суглобі. Часто виявляють тендовагініт, бурсит, зміни в сухожиллях і зв'язках.

Оцінку активності хвороби здійснюють на основі індексу DAS28 (табл. 1). Розрахунок вимагає від лікаря визначення кількості болючих та набряклих суглобів, наявність результату ШОЕ або СРБ та оцінку загального стану здоров'я за шкалою ВАШ пацієнтом:

DAS28 = 0,56 $\times$ кількість болючих суглобів $+0,28 \times$ кількість набряклих суглобів + 0,70 × Ln (ШОЕ/СРБ) + 0,014 × ВАШ.

Для полегшення розрахунку можна використовувати стаціонарні або офіційні онлайн калькулятори: https://www.das-score.nl/das28/DAScalculators/ dasculators.html, http://www.4s1 dawn.com/DAS28/ або в мобільному додатку DAS Calc [4].

\section{Функціональна недостатність суглобів (ФНС)}

$Ф \mathrm{HCl}$ - незначне обмеження рухів у суглобах, професійна здатність збережена.

ФНС II - обмеження рухів у суглобах, стійкі контрактури, помірне утруднення при самообслуговуванні, професійна здатність втрачена.

ФНС III - тугорухомість або ж повна відсутність рухів у суглобах, втрачена здатність до самообслуговування, хворий потребує сторонньої допомоги [3, 4, 6].

Критерії діагнозу РА (табл. 2) [5, 7].

Табличя 1. Визначення ступеня активності ревматоїдного артриту за DAS28

\begin{tabular}{|c|c|l|}
\hline Ступінь активності PA & Значення DAS28 & \multicolumn{1}{|c|}{ Інтерпретація } \\
\hline 0 & $<2,6$ & Ремісія \\
\hline I & $=2,6-3,2$ & Низька активність \\
\hline II & $=3,3-5,1$ & Середня активність \\
\hline III & $>5,1$ & Висока активність \\
\hline
\end{tabular}

Таблиця 2. Класифікаційні критерії ревматоїдного артриту згідно з ACR і EULAR 2010 р.

\begin{tabular}{|c|c|}
\hline А. Ураження суглобів & Бал* \\
\hline 1 великий суглоб & 0 \\
\hline 2-10 великих суглобів & 1 \\
\hline 1-3 малих суглобів (ураження великих суглобів наявне або відсутнє) & 2 \\
\hline 4-10 малих суглобів (ураження великих суглобів наявне або відсутнє) & 3 \\
\hline >10 суглобів (у тому числі щонайменше один малий суглоб) & 5 \\
\hline Б. Серологія (необхідним є результат $\geq 1$ тесту) & Бал* \\
\hline РФ і АЦЦП негативні & 0 \\
\hline РФ або АЦЦП наявні в низькому титрі & 2 \\
\hline РФ або АЦЦП наявні у високому титрі & 3 \\
\hline В. Показники гострої фази (необхідним є результат $\geq 1$ тесту) & Бал* \\
\hline Рівень СРБ в нормі та ШОЕ в нормі & 0 \\
\hline Рівень СРБ підвищений або підвищення ШОЕ & 1 \\
\hline Г. Тривалість симптомів & Бал* \\
\hline$<6$ тижнів & 0 \\
\hline$\geq 6$ тижнів & 1 \\
\hline
\end{tabular}

Примітка. * - потрібно додати число балів із кожної категорії [А-Г]; результат $\geq 6$ балів = підтверджений діагноз РА. 
Оцінювана популяція: пацієнти, в яких:

1) наявний клінічно виражений синовіїт щонайменше одного суглоба (припухлість);

2) наявність синовіїту неможливо пояснити іншим захворюванням.

Нижченаведені критерії стосуються пацієнтів, яких оцінюють вперше. Окрім цього, до групи хворих на РА необхідно віднести пацієнтів із типовими для РА ерозіями (узурами) або з довготривалою хворобою (у тому числі неактивною, при якій проводили лікування або не проводили), які раніше відповідали нижчевказаним критеріям (про що свідчать дані з історії хвороби).

Екстраартикулярні ознаки - ураження шкіри, серця, легень, судин, очей, нирок, нервової системи, селезінки та системи крові, а також неспецифічні ознаки - втома, втрата маси тіла, лихоманка, анемія (у разі хронічного перебігу) $[3,4,6]$.

Ревматоїдні вузлики - підшкірні, неболючі, на розгинальній поверхні, переважно на передпліччях, біля суглобів, їх еквіваленти розвиваються у внутрішніх органах, виявляють у 25 \% пацієнтів $[8,9]$. Гістологічно складаються з компонентів запалення та сполучної тканини.

Ураження серцево-судинної системи перебігає у вигляді перикардиту, часто клінічно асимптомного, переважно на пізній стадії захворювання. Спостерігають зміни в серцевому м'язі (кардіоміопатія), легенева гіпертензія, атеросклероз та тромбоемболічні епізоди (серцево-судинні катастрофи становлять найчастішу причину смерті хворих на РА) [3, 4, 6].

Ураження легеневої системи - плеврит, часто клінічно асимптомний; у легенях можуть з'являтися ревматоїдні вузлики, які розпадаються, кальцифікуються та можуть бути джерелом запалення. У деяких пацієнтів виявляють облітеруючий бронхіоліт та фіброз легень [3, 4, 6].

Ураження судин: васкуліти дрібних судин можуть викликати інфаркти, виразково-некротичний васкуліт, ліведо-ангіїт [3, 4, 6].

Зміни органа зору - сухий кератокон'юнктивіт із десквамацією при вторинному синдромі Шегрена, склерит, епісклерит, васкуліт сітківки [3, 4, 6].

Зміни в нирках пов'язані головним чином з небажаними ефектами лікарських засобів - інтерстиціальний нефрит, пієлонефрит. Вторинний амілоїдоз нирок $\epsilon$ ускладненням довготривалого активного неконтрольованого запалення, спричиненого РА $[3,4,6]$.
Зміни в нервовій системі - тунельні синдроми; поліневропатії, мононеврити частіше зумовлені проявами васкуліту; компресія корінців спинномозкових нервів внаслідок деструкції суглобів шийного відділу хребта. Ураження центральної нервової системи розвивається рідко [1].

Спленомегалію, лімфаденопатію підщелепних, шийних, пахових і ліктьових лімфовузлів, лейкопенію (нейтропенію) спостерігають при синдромі Фелті.

Ускладнення активного РА:

- вторинний системний амілоїдоз;

- вторинний артроз;

- системний остеопороз;

- остеонекроз;

- тунельні синдроми (синдром карпального каналу, синдроми стискання ліктьового, великогомілкового нервів);

- підвивихи в атланто-аксіальному суглобі, в тому числі з мієлопатією, нестабільністю шийного відділу хребта;

\section{- атеросклероз.}

\section{Лабораторно-інструментальна діагностика}

Загальний аналіз крові може виявляти нормохромну чи гіпохромну анемію, підвищення ШОЕ, а вміст лейкоцитів залежить від активності недуги.

Біохімічні дослідження використовують для встановлення активності перебігу ревматоїдного процесу: диспротеїнемія - збільшення вмісту глобулінів, особливо за рахунок $\gamma$ - і $\alpha_{2}$-фракцій; підвищення вмісту фібриногену, серомукоїду, сіалової кислоти, СРБ.

Імунологічні феномени:

1. Виявлення РФ у крові. РФ - аутоантитіла класу A, G, M, які синтезуються плазматичними клітинами синовіальної оболонки. 3 синовіальної оболонки РФ потрапляє в системний кровотік і реагує як аутоантиген з власними IgG. Утворені імунні комплекси ушкоджують синовіальну оболонку, стінки судин. Більше 70 \% пацієнтів є серопозитивними за РФ у периферійній крові, у решти пацієнтів - РФ не виявляють. При проведенні реакції Ваалер - Роуза для визначення РФ діагностично значущим $є$ титр 1:32; латекс тесту - 1:40.

2. Антитіла до циклічного цитрулінового пептиду (А-ССР) на сьогодні $\epsilon$ інформативним серологічним маркером РА зі специфічністю 95-99 \% і чутливістю 65-87\%. А-ССР визначають в 30-50 \% випадків при негативному РФ за умови РА, також можуть визначатися роками перед початком клінічних проявів.

3. Зростання концентрації IgG, IgM, IgA. 
4. Зниження кількості Т-лімфоцитів загальних та Т-супресорів.

5. Зростання концентрації феритину (>3000 нг/мл) вказує на хворобу Стілла (варіант системного перебігу РА), а ступінь підвищення корелює з активністю хвороби.

Дослідження синовіальної рідини проводять лише за наявності особливих показань: неприємні відчуття в ураженому суглобі (за умови достовірного діагнозу), для диференціальної діагностики артриту і артрозу, з метою виключення іншого захворювання, оскільки від цього залежить вибір програми подальшого обстеження і лікування хворого.

У синовіальній рідині хворих на РА нерідко виявляють рагоцити (Ra-cell) - нейтрофіли, у цитоплазмі яких розташовуються фагоцитовані імунні комплекси.

\section{Візуалізаційні методи дослідження суглобів}

- Рентгенографія кистей і стоп є основним методом діагностики та оцінки прогнозу РА. Рентгенографія суглобів (Steinbrocker, 1949) дозволяє встановити стадію РА [3, 6]:

І стадія - білясуглобовий остеопороз; відсутність деструктивних змін;

II стадія - білясуглобовий остеопороз із незначною деструкцією субхондральної кістки або ж без неї, незначне звуження суглобової щілини, поодинокі узури;

III стадія - білясуглобовий остеопороз із ознаками деструкції хряща та кістки; виражене звуження суглобової щілини; множинні узури, підвивихи; девіації кісток;

IV стадія - зміни; характерні для III стадії разом 3 анкілозом.

- За допомогою артросонографії (УЗД) при «ранньому» РА виявляють субклінічний синовіїт, а також периартикулярний набряк, гроноподібне потовщення синовіальної оболонки до 4-6 мм (панус), васкуляризація якої значна. На пізніх стадіях хвороби при УзД суглобів спостерігають прогресивне зменшення висоти суглобових хрящів, а товщина пануса сягає 10-12 мм (вираження васкуляризації варіює), виявляють узурацію субхондральної кістки раніше, ніж за допомогою рентгенографії, фіброзування та анкілози. Стан субхондральної кістки (остеопенія, остеосклероз) за допомогою артросонографії оцінити неможливо.

- Магнітно-резонансна томографія (МРТ) має найвищу серед інструментальних методів чутливість щодо виявлення кісткових ерозій, остеонекрозів, дозволяє оцінити стан хряща, сухожилків, м'язів, інших м'яких тканин, візуалізує кістковий мозок. Дає можливість рано виявити синовіїт, набряк кісткового мозку, який може випереджувати синовіїт.

- Комп'ютерна томографія (КТ) дозволяє значно раніше, ніж за допомогою рентгенографії, виявити деструктивні зміни в суглобах, є найкращим методом візуалізації субхондральних кіст (геод) при збереженій безперервності кіркового шару або із незначним його перериванням (при МРТ спостерігається незмінений МР-сигнал, внаслідок чого зміни можуть бути невиявленими). КТ ефективна при проведенні оцінки змін у шийному відділі хребта [4].

\section{Лікування}

Сучасні підходи до лікування РА зводяться до декількох основних принципів. При цьому в основі досягнення максимального терапевтичного успіху $\epsilon$ належне поєднання медикаментозної терапії, зокрема хворобомодифікуючих протиревматичних препаратів (ХМПРП), нестероїдних протизапальних препаратів (НПЗП) та глюкокортикоїдів (ГК) з нефармакологічними засобами, а саме фізіо-, праце- і психотерапією [5, 6].

Незмінною основою лікування хворих на РА залишається призначення одного із препаратів групи ХМПРП, принципи застосування яких протягом останніх десятиріч зазнали виражених змін не лише внаслідок появи нових, високоефективних лікарських засобів (біологічних агентів), а також завдяки зміні загальної стратегії - максимально раннє призначення (у період «вікна можливості») і часто доволі агресивна тактика, навіть у дебюті хвороби (М. A. Bukhari et. al., 2003; van Dongen H. et. al., 2007) [6]. Усі положення про лікування РА, згідно з сучасними тенденціями, зводяться до правила «treat-to-target» - лікування до мети. У даному випадку ціллю $є$ мінімальна активність або ремісія РА.

У 2010 р. експертами EULAR розроблено рекомендації щодо лікування хворих на РА з використанням синтетичних та біологічних ХМПРП та глюкокортикоїдів, які щороку коригують та доповнюють.

Рекомендації EULAR щодо менеджменту ревматоїдного артриту синтетичними чи біологічними ХМАРПами: перегляд 2019 р. [джерело: http:// rheumnow.com/content/eular-recommendationsmanagement-rheumatoid-arthritis-2019].

\section{Загальні принципи}

1. Лікування хворих на РА повинно бути спрямоване на найкращий догляд і має ґрунтуватися на спільному рішенні між пацієнтом та ревматологом.

2. Рішення щодо лікування ґрунтуються на активності хвороби, питаннях безпеки та інших факторах, 
таких як коморбідність та прогресування структурних ушкоджень.

3. Ревматолог - це спеціаліст, який повинен забезпечувати всебічний супровід пацієнта з РА.

4. Пацієнтам необхідно забезпечити доступ до медикаментозних засобів із різним механізмом дії у зв'язку з гетерогенністю даного захворювання; вони можуть потребувати кілька послідовних методів лікування протягом усього життя.

5. РА несе високі індивідуальні, медичні та соціальні витрати - усе це має бути враховане лікарем-ревматологом у призначенні обстеження та лікування хворого.

Оновлені рекомендації EULAR щодо менеджменту ревматоїдного артриту (2019)

1. Терапія ХМАРПами повинна бути розпочата відразу після встановлення діагнозу РА.

2. Основною ціллю лікування $є$ досягнення стійкої ремісії чи низької активності у кожного пацієнта.

3. Необхідно здійснювати частий моніторинг за умови активності хвороби (кожні 1-3 місяці); якщо не спостерігається покращення протягом 3 місяців після старту терапії або ціль не досягнута протягом 6 місяців, лікування повинно бути кориговане.

4. Метотрексат (MTX) (15-25 мг щотижня) є препаратом першої лінії.

5. У пацієнтів з протипоказаннями до призначення МTX (чи ранньою непереносимістю) - лефлуномід (20 мг на добу) чи сульфасалазин (2-3 г на добу) повинні бути призначені як основа первинної стратегії лікування РА.

6. Короткотривалу ГКС-терапію застосовують при початковому призначенні синтетичних ХМАРПів або за умови зміни стратегії лікування (зазвичай: терапіямісток 8 мг метилпреднізолону орально протягом 2 місяців), проте дозу ГКС потрібно знижувати аж до повної відміни, як тільки дозволяє клінічна ситуація.

7. Якщо ціль лікування не досягнута та за умов негативного прогнозу - необхідно розглянути можливість призначення інших синтетичних ХМАРПів.

8. Якщо ціль лікування не досягнута за допомогою першого синтетичного ХМАРПу, за умов наявності негативних прогностичних факторів - біологічні та цільові синтетичні ХМАРПи (інгібітори янус-кінази) повинні бути призначені (а саме: абатацепт, адалімумаб, етанерцепт, інфліксимаб, голімумаб, цертолізумаб, ритуксимаб, тоцилізумаб).
9. Біологічні та цільові синтетичні ХМАРПи потрібно комбінувати зі звичайними синтетичними ХМАРПами; у пацієнтів, які не можуть отримувати звичайні синтетичні ХМАРПи з метою базисної терапії, інгібітори IL-6 і цільові синтетичні ХМАРПи (інгібітори янус-кінази) мають деяку перевагу над біологічними ХМАРПами.

10. Якщо біологічні чи цільові синтетичні ХМАРПи не спрацювали, необхідно розпочати лікування іншим біологічним ХМАРПом чи цільовим синтетичним ХМАРПом; якщо один з інгібіторів ФНП-а не спрацював, пацієнт може отримувати агент з іншим механізмом дії або інший інгібітор ФНП-а.

11. Якщо пацієнт досягнув стійкої ремісії після припинення ГКС, можна розглянути можливість перспективи зменшення біологічних чи цільових синтетичних ХМАРПів, особливо якщо вони поєднуються зі звичайними синтетичними ХМАРПами.

12. Якщо пацієнт перебуває у стійкій ремісії, можна розглядати перспективу зниження дози звичайних синтетичних ХМАРПів.

У комплексному лікуванні РА для досягнення найкращого ефекту варто використовувати можливості фізіотерапії, кінезитерапії, навчання пацієнта прийомам самомасажу, здорового харчування та прийнятного балансу активності та відпочинку.

На допомогу медичним працівникам - лікарям, реабілітологам, медичним сестрам, а також самим пацієнтами з РА у вільному доступі $є$ ресурс Medscape та Mayo Clinic. На жаль, поки що англійською мовою, проте національні навчальні програми уже розпочали активний професійний розвиток медичних сестер, про що свідчить введення секцій для медичних сестер у програми конференцій та он-лайн навчання.

Висновки. На сучасному етапі для діагностики та лікування РА існують доволі чіткі рекомендації, які охоплюють всі можливі варіанти перебігу хвороби. Проте для досягнення успіху в цьому тривалому процесі та покращення прогнозу необхідна співпраця між пацієнтом та медичною командою (лікар, медична сестра, реабілітолог, психолог та ін.). Вона повинна включати навчання пацієнта про його хворобу, іï перебіг та довготривале лікування, а також лікувальну фізкультуру, фізіотерапію та адаптацію до реальності з урахуванням можливого впливу хвороби на соціальне та особисте життя пацієнта. 


\section{СПИСОК ЛІТЕРАТУРИ}

1. Головач І. Ю. Клінічні випадки прижиттєвої діагностики ревматоїдного менінгіту з гістологічною верифікацією / І. Ю. Головач, Є. Д. Єгудіна // Український ревматологічний журнал. - 2018. - № 74 (4). - С. 25-31.

2. Насонова В. А. Ревматоїдний артрит / В. А. Насонова, В. Лайн. - М. : Медицина, 1983. - 239 с.

3. Національний підручник з ревматології / за ред. В. М. Коваленка, Н. М. Шуби. - К. : Моріон, 2013. - 672 с.

4. Практичний посібник з внутрішньої медицини, або кишенькова книжечка сімейного лікаря : посібник для студентів медичних закладів вищої освіти IV рівня акредитації, лікарів-інтернів, лікарів загальної практики сімейної медицини, терапевтів : у 2 ч. / [Н. В. Пасєчко, Н. І. Ярема, Л. П. Мартинюк та ін.] ; за ред. професорів Н. В. Пасєчко, Н. І. Яреми. - Тернопіль : Підручники і посібники, 2019. - 432 с.

5. Уніфікований клінічний протокол первинної, вторинної (спеціалізованої), третинної (високоспеціалі- зованої) медичної допомоги та медичної реабілітації «Ревматоїдний артрит»: наказ Міністерства охорони здоров'я України від 11.04.2014 р. № 263.

6. Хіміон Л. В. Тактика ведення хворих на ревматоїдний артрит лікарем загальної практики - сімейним лікарем / Л. В. Хіміон, О. Б. Ященко, С. В. Данилюк // Семейная медицина. - 2016. - № 2 (64). - С. 6-15.

7. Aletaha D, Neogi T, Silman A J, et al. 2010 Rheumatoid arthritis classifi cation criteria: an American College of Rheumatology/European League Against Rheumatism collaborative initiative / D. Aletaha, T. Neogi, A. J. Silman [et al.] // Ann. Rheum. Dis. - 2010. - Vol. 69. - P. 1580-1588.

8. Highton J. The Rheumatoid nodule: peripheral or central to rheumatoid arthritis? / J. Highton, P. A. Hessian, L. Stamp // Rheumatology (Oxford). - 2007. - Vol. 46. - P. 1385.

9. Sayah A. Rheumatoid arthritis: a review of the cutaneous manifestations / A. Sayah, J. C. 3rd. // English J. Am. Acad. Dermatol. - 2005. - Vol. 53. - P. 191.

Отримано 26.11.20 